\title{
Organization's Entrepreneurial Behaviors: A Study on Malaysian State Government Links Companies (SGLCS) Practices
}

\author{
Ahmad Raflis Che Omar ${ }^{1} \&$ Suraiya Ishak ${ }^{2}$ \\ ${ }^{1}$ School of Management Studies, Faculty of Economics and Management, Universiti Kebangsaan Malaysia, \\ Bangi, Malaysia \\ 2 School of Social Development and Environmental Studies, Faculty of Social Sciences and Humanities, \\ Universiti Kebangsaan Malaysia, Bangi, Malaysia \\ Correspondence: Suraiya Ishak, School of Social Development and Environmental Studies, Faculty of Social \\ Sciences and Humanities, Universiti Kebangsaan Malaysia, 43600 Bangi, Malaysia. E-mail: suraiya@ukm.my
}

Received: January 16, 2013 Accepted: March 29, 2013 Online Published: April 25, 2013

doi:10.5539/ass.v9n8p87 URL: http://dx.doi.org/10.5539/ass.v9n8p87

\begin{abstract}
Performance improvement requires new set of behaviors. It is posited that corporate performance can be improved through entrepreneurial behaviors. As far as government links companies (GLCs) are concern, higher performance can be derive from adoption of pure market behaviors. This study attempts to evaluate the practice of corporate entrepreneurial behavior by Malaysian state government links companies (SGLCs). This study employs survey to solicit information regarding entrepreneurial behaviors from selected SGLCs. The findings reveal that most SGLCs have adopted corporate entrepreneurial behavior in their operations. Nevertheless, the entrepreneurial dimensions have been differently emphasized due to most priority has been given to innovation, followed by risk-taking and pro-activeness. However, ANOVA analysis shows no significant differences in each entrepreneurial dimension across different samples. From the interview data, it was found that pure entrepreneurial behavior practices had been constrained by the nature of GLCs conflicting identity and insufficient of internal competencies and resources.
\end{abstract}

Keywords: entrepreneurial, government link companies (GLC), corporate entrepreneurial, Malaysia

\section{Introduction}

Government link companies (GLCs) have been well known of their roles duality that consists of serving the public interest as well as attaining the commercial objectives (Rudner 1975; Bozec \& Boujenoui 2004; Luke \& Verrynne, 2006). Their legal personality can either be expressed through special constituent act or by incorporation under the general companies' legislation. The government owns equity in private firms for specific reasons such as to ease economic development and to avoid collapse or force closure of major local private enterprises which have significant national interest (Bozec \& Boujenoui, 2004: 80; Abdul-Rashid et al., 2007). Profit generating is rarely the ultimate reason for GLCs' establishment. Therefore, GLCs unique characteristic has been lies between serving the nation and society interest as well as attaining profit objectives. The situation led to the incessant problems and conflicts in GLCs operation. Conflict and problems pertaining GLCs operations and performance have prolonged discussed since 1970s by many authors, including Abdul-Rashid et al. (2007), Thillainathan (1976), Rudner (1975) and Sherwood (1971). Furthermore GLCs or state enterprises in most countries have been associated with inefficiencies and poor performance record (Bozec \& Breton, 2003; Astami et al., 2010).

Currently, entrepreneurial behavior has become one of the mainstream topics for deliberating business performance issues. It has been recognized as an important source for organizations' growth and performance rejuvenation. The general topic of entrepreneurial behavior has inspired voluminous research aimed at explaining adoption of entrepreneurial behaviors by different type of organizations, including small firms (Gronum et al., 2012; Madrid-Guijarro et al., 2009; Vermeulen 2005; Gudmundson et al., 2003) and public organizations (Bozec \& Breton, 2003; Luke \& Verreynne, 2006; Kropp \& Zolin, 2008; Moore \& Jie, 2006). Therefore, this study elaborates on corporate entrepreneurial behaviors practices by Malaysian state government link companies (SGLCs). This study contributes to an understanding of corporate entrepreneurial behaviors practiced by a group of hybrid entities, which lie in the continuum of a pure government agencies and pure private entities 
(Abdul-Rashid et al. 2007).

Therefore the objectives of this study are as follows:

1) To identify practices of entrepreneurial behaviors by Malaysian state GLCs' operation;

2) To identify challenge(s) that distorts application of pure entrepreneurial behaviors by GLCs.

\section{Literature Review}

New public management (NPM) has called for radical changes in public sector management. It calls for emulation of private approach in conducting government businesses (Noore, 2006; Bozec \& Boujenoui, 2004). NPM is a set of contemporary administrative changes aimed at improving efficiency and performance in the delivery of public services. NPM involves application of private values and management tools as well as market based mechanisms for delivering public services (Luke \& Verreynne, 2006). As far NPM is concern, government related entities are moving towards adoption of energetic behaviors that similar to corporate counterparts. Two global changes underlying the institutionalization of corporate culture within government entities' are commercialization and privatization (Luke \& Verreynne, 2006; Bozec \& Boujenoui, 2004). Commercialization refers to the re-orientation of firms' objectives away from social targets and inclining towards profitability targets. Meanwhile, privatization refers to the structural adaptation which involved legal transfer of public ownership to private hands (Bozec \& Boujenoui, 2004).

Privatization is an important mean to overcome economic and social drawbacks persist in state enterprises management, functions and performance (Antoncic \& Hisrich, 2003; Zahra et al., 2000). Therefore, privatization contributes to entrepreneurial outcomes and improved organization's performance and growth. Privatization led towards entrepreneurial-based behaviors among the public or government-related agencies. This is in line with Antoncic \& Hisrich (2003) whom suggested that privatization as pivotal to corporate entrepreneurship, due to privatization provides environment to ease entrepreneurial activities. Nevertheless, the effect of privatization varies across different countries and companies (Zahra et al., 2000). In addition, effective privatization is relatively difficult to achieve by emerging economies compared to the developed counterparts. Therefore, it shows that contextual factor plays significant role to determine practices of entrepreneurial behaviors and its effectiveness.

Entrepreneurship had been described by Covin and Slevin (1991) as "dimension of strategic posture represented by a firm's risk-taking propensity, tendency to act in competitively aggressive, proactive manners, and reliance on frequent and extensive product innovation". Therefore it can be understood that organization as a whole can behave entrepreneurially. Corporate entrepreneurship or intrapreneurs has become an important source for creating organizations' competitive advantage and performance revitalization (Certo et al., 2009; Antoncic \& Hisrich, 2003; Zahra et al., 2000). According to Certo et al. (2009) and Antoncic \& Hisrich (2003), corporate entrepreneurship refers to a set of firm wide activities that center on the discovery and pursuit of new opportunities through innovation, new business creation or introduction of new business models. Many studies have indicated positive relationship between firms' entrepreneurial posture and performance (Certo et al., 2009; Runyan et al., 2008; Antoncic \& Hisrich, 2004; Goosen et al., 2002). However, according to Antoncic and Hisrich (2003) and Zahra et al (2000), organizations and countries may differ in the level of entrepreneurship demonstrated as well as the expected outcomes. Furthermore, according to Zahra et al (2000) promoting entrepreneurial behaviors are far more difficult in emerging economy. As a result, it is expected that entrepreneurial behaviors among Asian state-owned enterprises may possess certain trend or characteristics due to its specific context.

There are three major dimensions of entrepreneurial behaviors comprises of innovativeness, proactive and risk taking (Covin \& Slevin, 1991; Lumpkin \& Dess, 2001; Wiklund \& Shepherd, 2004). Innovation is one of the most important foundations in entrepreneurial behavior (Zahra et al., 2000). Innovation leads to introduction of new products, processes, technologies, systems, techniques, resources and capabilities that enhance the competitive advantage of particular firms. According to Fernández and Wise (2010) there are two types of innovation comprises of invented innovation and ingested innovation. Invented innovation refers to discovery or invention of an entirely new process, technology, or product in which no other organization had generated the idea before. Meanwhile, ingested innovation refers to the processes, technologies and products which are learned, adopted and carried out for the first time by particular organization. Apart from innovation, entrepreneurial orientation also includes the calculated risk-taking (Zahra et al., 2000). Risk taking refers to strategic decisions that involve uncertainties (Rauch et al., 2009). Uncertainty refers to situations in which the probability of a future outcome cannot be determined in advance (Certo et al., 2009). Meanwhile pro activeness is the opportunity-seeking, forward-looking perspective characterized by introduction of new products ahead from 
competitors and satisfies future demand (Rauch et al., 2009; Tang et al., 2007).

Covin \& Slevin (1991) had proposed a firm-level model of entrepreneurship. According to Covin \& Slevin (1991) there are four internal variables which determined entrepreneurial posture of particular organization. The internal independent variables comprise of top management value and philosophies, organizational resources and competencies, organizational culture and organizational structure. Organization entrepreneurial practice is a value-laden decision that reflects top management values. Availability of internal resources and competencies can accelerates entrepreneurial practices as entrepreneurial postures are resource-consume activities. Organization culture refers to the shared values and beliefs and imposed commitment to entrepreneurial behavior among organizations' members. Meanwhile organization structure refers to specific arrangement of workflow and authority relationship within organization. Organization's structure determines the level of entrepreneurial behavior as entrepreneurial behavior requires certain structure that permits flexibility and rapid decision-making. Therefore, these variables serve as predictors that explain differences in entrepreneurial behavior within different micro context.

\section{Method}

This study employs triangulation approach that combines quantitative and qualitative method simultaneously. Triangulation refers to the use of several research methods to investigate the same phenomenon or objects (Babbie, 2004: 113). It is considered as valuable research strategy as all methods possess some strengths and weaknesses; thus, combination of various methods is expected to improve research findings (O'Donnell, 2011; Runyan et al., 2008). As far as this study is concerns, survey and interviews had been used to gather data from the respondents.

Self-administered questionnaires were administered to managers of each SGLC in four states, namely Kedah, Selangor, Johor and Kelantan. The states were selected from official classification which had categorized the states into two groups namely the developed states and less-developed states. The classification was made according to their respective development composite index. Selangor and Johor have fall under the developed group, while Kedah and Kelantan are classified under the less-developed group. The selection of states from different development background is to ensure representativeness of different development background. The questionnaire consists of three dimensions of entrepreneurial behavior (also known as entrepreneurial orientation) comprises of pro-active, risk-taking and innovation. All dimensions have been measured by the interval level of measurement anchored with scales that ranged from 1 (very disagree) to 7 (very agree). The questionnaires have been distributed to 60 SGLCs in four states and only 32 (53 percent) have completed the questionnaire (Table 1).

Table 1. Survey's respondents

\begin{tabular}{lc}
\hline State & Number of participated SGLCs \\
\hline Kedah & 11 \\
Selangor & 5 \\
Johor & 3 \\
Kelantan & 13 \\
Total & $\mathbf{3 2}$ \\
\hline
\end{tabular}

In addition to the questionnaire, in-depth interview was also conducted with managers or any of the company's top management representatives. The purpose of the interview is to comprehend possible challenges that hinder application of entrepreneurial behaviors among SGLCs. The informants selection has been made through purposive sampling technique that taken into consideration respondents' co-operation and availability of time. Finally, three informants were involved in the interview and their identity retained as anonymous. The interview data were analyzed through content analysis in a way that interpretation of the overall meaning has been made based on the informant's conversation.

\section{Analysis}

\subsection{Measurement Consistency}

Internal consistency test was conducted to evaluate measurement items' consistency. Table 2 summarizes the Cronbach Alpha result for the measurement. 
Table 2. Internal consistency of corporate entrepreneurship measurement

\begin{tabular}{ll}
\hline Entrepreneurship Dimension & Alpha \\
\hline Innovation & 0.814 \\
Pro-Active & 0.859 \\
Risk-Taking & 0.869 \\
\hline
\end{tabular}

The result as in Table 2 indicates an acceptable level of alpha which represents items consistency of particular measurement. Factor analysis was also conducted to identify structural dimensions contained in the data. Prior to factor analysis, KMO and Barlett test has been evaluated in order to the sampling adequacy of the data for factor analysis. Table 3 indicates the results of Kaiser-Meyer-Olkin and Bartlett test of sample adequacy.

Table 3. Kasier-Meyer-Olkin (KMO) and Barlett test

\begin{tabular}{llc}
\hline Kaiser-Meyer-Olkin Measure of Sampling Adequacy & $\mathbf{0 . 6 9 8}$ \\
\hline Bartlett Test of Sphericity & Approx. Chi-square & 414.846 \\
& Df & 136 \\
& Sig. & 0.000 \\
\hline
\end{tabular}

Based on Table 3, the data fits the sampling adequacy requirement with KMO value of 0.698, while the Bartlett test indicates existence of correlation among the items in the data population $[\chi 2=414.846$ and $p=0.000]$. Therefore, principal component analysis (PCA) has been carried out specifically to identify the underlying common factors of the data. The result of PCA analysis is shown in Table 4.

Table 4. Total variance explained

\begin{tabular}{lccc}
\hline Component & \multicolumn{3}{c}{ Eigenvalues } \\
\hline & Total & \% of variance & Culumative \% \\
1 & 7.771 & 45.712 & 45.712 \\
2 & 2.139 & 12.581 & 58.293 \\
3 & 1.906 & 11.211 & 69.504 \\
4 & 1.298 & 7.637 & 77.141 \\
5 & 0.734 & 4.318 & 81.459 \\
\hline
\end{tabular}

From Table 4, the single factor had accounted up to 45.7 percent of the explanations on the variance of the data. Therefore, further analysis has been conducted by using the single factor corporate entrepreneurship measurement.

\subsection{Descriptive and Inferential Test}

The mean of the entrepreneurial orientation of SGLCS for each state are shown in Table 5. Overall, the SGLCs entrepreneurial orientations (EO) have means ranged from 69.00 to 74.72. The means show that most of SGLCs have reached the upper level scores as most of their scores exceed 50 points. The means for SGLC of Johor is 69.00 ( $\mathrm{SD}=15.87)$, followed by Selangor GLCs 71.60, $(\mathrm{SD}=14.67)$ Kelantan GLCs of $74.462(\mathrm{SD}=14.88)$ dan Kedah SGLCs of 74.723 (SD=14.48). 
Table 5. Mean \& standard deviation of EO for each states

\begin{tabular}{llll}
\hline States & N & Min & SD \\
\hline Kedah & 11 & 74.723 & 14.48 \\
Selangor & 5 & 71.600 & 14.67 \\
Johor & 3 & 69.000 & 15.87 \\
Kelantan & 13 & 74.462 & 14.88 \\
Total & 32 & 73.594 & 14.17 \\
\hline
\end{tabular}

In order to identify differences in adoption of corporate entrepreneurship among SGLCs, one way anova had been conducted. The Levene test shows that the population variance is almost the same $[p=0.07 ; p>0.05]$. The ANOVA test indicates no significant differences in entrepreneurial orientation (EO) among different SGLCs (Table 6).

Table 6. ANOVA test of differences in EO

\begin{tabular}{lllll}
\hline & Sum of squares & DF & F & Sig. \\
\hline Between groups & 107.106 & 3 & 0.163 & 0.920 \\
Within Groups & 6122.613 & 28 & & \\
Total & 6229.719 & 31 & & \\
\hline
\end{tabular}

The result shows the EO level for Malaysian SGLCS are almost similar as they have been operating within similar macro environment structure. Post Tukey comparison shows that most significant differences is between Johor SGLCs (mean= 69.00) and Kedah SGLCs (mean= 74.72).

Table 7 shows the detailed of EO according to the three dimensions. From the table we found that innovation gained highest mean scores (mean $=36.9$; $\mathrm{SD}=7.63$ ); followed by risk taking (mean $=18.7$; $\mathrm{SD}=4.86$ ) and proactive (mean=17.97; $\mathrm{SD}=7.63$ ). This result indicates that the SGLCs, EO have been emphasizing on innovation behavior either in product or process.

Table 7. Mean \& standard deviation of EO dimensions

\begin{tabular}{lll}
\hline $\mathbf{N}=32$ & Min & SD \\
\hline Pro-active & 17.97 & 4.24 \\
Innovative & 36.94 & 7.63 \\
Risk-taking & 18.69 & 4.86 \\
\hline
\end{tabular}

Furthermore, ANOVA test in conjunction with the mean differences in the three dimensions had been executed to evaluate differences. Results indicate no significant differences (Table 8). Therefore, SGLCs behaviors in each of the three dimensions are statistically indifferent.

Table 8. ANOVA test of differences in EO 3 dimensions

\begin{tabular}{llrrll}
\hline & & Sum of squares & DF & F & Sig. \\
\hline Pro-active & Between groups & 27.228 & 3 & 0.480 & 0.699 \\
& Within Groups & 529.741 & 28 & & \\
& Total & 556.969 & 31 & & \\
Innovations & 72.973 & 3 & 0.393 & 0.759 \\
& Between groups & 1732.902 & 28 & & \\
& Within Groups & 1805.875 & 31 & & \multirow{2}{*}{0.554} \\
& Total & 51.871 & 3 & 0.711 & \\
& Between groups & 681.004 & 28 & & \\
& Within Groups & 732.875 & 31 & & \\
& Total & & & & \\
\hline
\end{tabular}




\section{Discussion}

The analysis reveals that Malaysian SGLCs had re-aligned their behavior towards the adoption of entrepreneurial-based behaviors. The trend has been in line with the Malaysian federal government GLCs transformation program conducted massively since 2004. The transformation program involves review and development of policies to facilitate new environment that facilitates performance improvement. Among the improvement is to encourage more entrepreneurial behavior among the GLCs. As a result, entrepreneurial behaviors of particular SGLCs are indifferently practices as showed in Table 5 and 6 . Entrepreneurial orientation behavior had rest upon three main pillars comprises of innovativeness, pro-active and risk-taking. The application of entrepreneurial dimensions will enhance companies' capacity to compete efficiently and effectively in the market as well as to improve profits due to increased capacity. Based on Table 7, the most adopted dimension of entrepreneurial behavior is innovation (mean 36.94; SD 7.63), followed by risk-taking (18.69; SD 4.86) and pro-activeness (mean 17.97; SD 4.24). The explanation to such phenomenon can be relates to the nature of GLCs hybrid identity ("two-faced organization") which fall under Covin \& Slevin (1991) description of the organizations structure. Due to SGLCs hybrid identity, the risk-taking and pro-activeness had been constrained in order to re-balance the profit objective with social and political motives. As the parent's company (SDEC and its equivalent) are accountable directly to the government and people, SGLCs investment are publicly exposed and accountable to large number of stakeholders. Therefore, SGLCs managements are required to strictly abide to specific procedures and eventually distort its' ability to act pro-actively and taking risk. As innovation can be conducted in the simplest mode, such as ingested incremental product innovation or administrative innovation, it is relatively convenience to adopt innovative behavior compared to the other two entrepreneurial dimensions. The quantitative findings are further explained by interviews' transcription presented in the following paragraph.

\section{Manager A, Company ABC:}

"Do not compare us with ordinary players. (For an)...example. We came across these situations frequently. There are some valuable business opportunity and we need to sell our land in order to grab the opportunities. However, as the assets endowed to our company by state government we had to go through a series of rigid bureaucratic procedures and approval. (Business) opportunities never wait as you wish. As the result...we had to forego the opportunity. I had worked in few ordinary private companies before...they can respond to most opportunities and act faster than GLCs due to more flexibilities and autonomy."

\section{CEO B, Company XYZ:}

"One of our subsidiary involved in sewerage activities (it delivers services) that cater the need of No-name state. The operational costs are enormous; (however)...GLC cannot pass the extra cost to customers (people). We are not allowed to do so (by the government). Sometime the revenue (even) is lesser than the operation cost. Some people reluctant to pay the sewerage bill, but we cannot stop from performing the task. We can't even stop the service to people who didn't want to pay us, because the water will flows into the tanks and we cannot separate it according to which house or customers it belongs to. See...we are doing more social job than the commercial activity. It's either we behave as true business player and neglect the people's well-being or promote the people's well-being with lesser income, that's the only choice we have. Most of the times, when we need for some capital expenditure we will apply it from the government and you know the granted amount was very limited. So how to do innovation when you cannot commit good R\&D? Or do a risk-taking investment when your normal business activity is already full of challenge and risks?"

\section{CEO C, Company DEF:}

"One of our main constraint is that we are unable to hire bright and high entrepreneur orientation general managers to lead this performance transformation task. For example few months ago, we had interviewed a very excellent candidate for general manager post. He's a experienced corporate manager with good ideas, clear visions, strategize and keen of joining our operations. We really excited to have him with us. Unfortunately we can't afford to pay his expected salary. I agreed that he had requested for reasonable salary in parallel to his corporate experiences and qualification... He even lowered his expected salary a little bit in order to give us more flexibility. But we still can't afford it and I don't think we are fair enough to him if we pay any lesser amount (because) compared to what he's been getting from current employer. You know...my pay as the CEO of this company is even lower than what he's been getting out there or his expected salary." 
Based on the above transcriptions, findings regarding constraints of SGLCs entrepreneurial behaviors are derived as follows:

1) GLCs ability to act promptly and to beat other competitors has been subjected to certain boundary. Therefore, pro-activeness and risk-taking are relatively restricted entrepreneurial behavior compared to innovation. Innovative dimension gained higher score due to variability of options in performing innovative conduct. For example, management can opt to perform product (service) innovation, technological innovation, administration or process innovation. The innovation can also occurred in the simplest form such as redesigning the current internal procedures that contributes to cost-saving or delivery improvement (known as incremental innovation); or a relatively cheaper innovation by imitating others discovery (ingested innovation);

2) The syndrome of "two-faced organization" creates difficulties for GLCs to be a true market player. The possession of government DNA led to the inheritance of many social and unprofitable obligations that parallel with the role of government and national interest. The fact was proved by interview respond from CEO B of Company XYZ. In addition, interview with Manager A of company ABC, reiterated that GLCs business landscape is not equivalent to the private counterparts due to the social obligation imposed on GLCs.

3) In addition, GLCS also encountered severe resources problems such as hiring capable management team as well as fund. This was proved by CEO B respond when mentioning scarcity of fund to finance the operational and capital expenditures. Such finding reiterates Zahra et al (2000) that inadequate resources and capabilities hinder entrepreneurial orientation behaviors within privatized state-owned enterprises and eventually distort privatization ability to rejuvenate GLCs performance in most emerging economies.

The three findings are closely related with some of the internal variables mentioned by Covin \& Slevin (1991), namely the organizational structure as well as internal resources and competencies. Therefore, we conclude that GLCs have attempted to improve their performance through adotion of entrepreneurial behaviors. Nevertheless, GLCs had inherited more government DNA compared to commercial entities' DNA. Although GLCs have been assigned with profit objective, the reality has yet converged with ideal situation. This is in line with Bozec et al. (2004) who state that government ownership in private firms was meant to accommodate economic development or other nation interests. Therefore most privatization has been done in light of retaining most of the original macro and internal structure. As a result the level of entrepreneurial behavior of respective GLCs remained at the beginning stage.

Future study should investigate the impact of EO to companies' financial performance. This is important in order to understand the extent of constrained EO impact on SGLCs performance. Future study also can investigate the impact of different types of privatization to entrepreneurial behaviors. It also potentially explained the level of entrepreneurial orientation adopted by companies in parallel with Zahra et al (2000) study. In addition, it is also worth to study the innovation type that mostly adopted by GLCs.

\section{Conclusion}

Performance improvement requires new set of behaviors. The GLCs' management has realized the important of entrepreneurial behavior for performance rejuvenation. Therefore, this study shows that Malaysian GLCs entrepreneurial behaviors are indifferent across companies. Most of the GLCs have implemented innovative behavior at the higher level compared to risk-taking and pro-activeness dimensions. The adoptions of entrepreneurial behavior of particular GLCs have been constrained by structural-based problem which arise from their hybrid identity and internal resources availability. Therefore, the hybrid identity and internal resources/competencies insufficiencies have become obstacles to a pure entrepreneurial behavior among particular GLCs.

\section{References}

Abdul-Azizi, A. R., Jaafar, M., \& Hussin, A. A. (2007). Are government-linked construction companies in Malaysia still valid? The indegenious contractors' perspective. Construction Management and Economics, 25, 1009-1019. http://dx.doi.org/10.1080/01446190701598640

Antoncic, B., \& Hisrich, R. D. (2003). Privatization, corporate entrepreneurship, and performance: testing a normative model. Journal of Developmental Entrepreneurship, 8(3), 197-218.

Astami, E. W., Tower, G., Rusmin, R., \& Neilson, J. (2010). The effect of privatization on performance of state-owned-enterprises in Indonesia. Asian Review of Accounting, 18(1), 5-19. http://dx.doi.org/10.1108/13217341011045971

Babbie, E. (2004). The Practice of Social Research (10th ed.). Belmont United States: Wadsworth/Thomson 
Learning.

Bozec, R., \& Breton, G. (2003). The impact of the corporatization process on the financial performance of Canadian state-owned enterprises. The International Journal of Public Sector Management, 16(1), 27-47. http://dx.doi.org/10.1108/09513550310456409

Bozec, R., Zéghal, D., \& Boujenoui, A. (2004). The effect of the reform of Canadian state-owned enterprises on major corporate governance mechanisms. Australian Journal of Public Administration, 63(2), 79-94. http://dx.doi.org/10.1111/j.1467-8500.2004.00380.x

Certo, S. T., Moss, T. W., \& Short, J. C. (2009). Entrepreneurial orientation: an applied perspective. Business Horizons, 52, 319-324. http://dx.doi.org/10.1016/j.bushor.2009.02.001

Covin, J. G., \& Slevin, D. P. (1991). A conceptual model of entrepreneurship as firm behavior. Entrpreneurship Theory and Practice, 16, 7-25.

Fernández, S., \& Wise, L. R. (2010). En exploration of why public organizations "ingest" innovations. Public Administration, 88(4), 979-998. http://dx.doi.org/10.1111/j.1467-9299.2010.01857.x

Goosen, C. J., Conning, T. J., \& Smit, E. M. (2002). Corporate entrepreneurship and financial performance: the role of management. South African Journal of Business Management, 33(4), 21-27.

Gronum, S., Verreynne, M. L., \& Kastelle, T. (2012). The role of networks in small and medium-sized exterprise innovation and firm performance. Journal of Small Business Management, 50(2), 257-282. http://dx.doi.org/10.1111/j.1540-627X.2012.00353.x

Gudmundson, D., Tower, C. B., \& Hartman, E. A. (2003). Innovation in small businesses: culture and ownership structure do matter. Journal of Developmental Entrepreneurship, 8(1), 1-17.

Kropp, F., \& Zolin, R. (2008). US Federal government entrepreneurship: new enterprise structures. Journal of Small Business and Enterprise Development, 15(3), 595-605. http://dx.doi.org/10.1108/14626000810892373

Luke, B., \& Verreynne, M. L. (2006). Exploring etrategic entrepreneurship in the public sector. Qualitative Research in Accounting \& Management, 3(1), 4-26. http://dx.doi.org/10.1108/11766090610659724

Lumkin, G. T., \& Dess, G. G. (2001). Linking two dimensions of entrepreneurial orientation to firm performance: the moderating role of environment and industry life cycle. Journal of Business Venturing, 16(5), 429-451. http://dx.doi.org/10.1016/S0883-9026(00)00048-3

Madrid-Guijarro, A., Garcia, D., \& Van Auken, H. (2009). Barriers to innovation among Spanish manufacturing SMEs. Journal of Small Business Management, 47(4), 465-488. http://dx.doi.org/10.1111/j.1540-627X.2009.00279.x

Moore, S., \& Jie Wen, J. (2006). Reform of state owned enterprises and challenges in China. Journal of Technology Management, 1(3), 279-291.

O’Donnell, A. (2011). Small firm marketing: synthesizing and supporting received wisdom. Journal of Small Business and Enterprise Development, 18(4), 781-805. http://dx.doi.org/10.1108/14626001111179802

Rauch, A., Wiklund, J., Lumpkin, G. T., \& Frese, M. (2009, May). Entrepreneurial orientation and business performance: an assessment of past research and suggestions for the future. Entrepreneurship Theory and Practice, 761-787. http://dx.doi.org/10.1111/j.1540-6520.2009.00308.x

Rudner, M. (1975). Nationalism, planning and economic modernization in Malaysia: the politics of beginning development. Sage Research Paper, 3.

Runyan, R., Droge, C., \& Swinney, J. (2008). Entrepreneurial orientation versus small business orientation: what are their relationship to firm performance? Journal of Small Business Management, 46(4), 567-588. http://dx.doi.org/10.1111/j.1540-627X.2008.00257.x

Sherwood, F. P. (1971). The problems of the public enterprise. In F. W. Riggs (Ed.), Frontiers of Development Administration (pp. 348-372). United States: Duke University Press.

Siddiquee, N. A. (2006). Public management in Malaysia. International Journal of Public Sector, 19(4), 339-358. http://dx.doi.org/10.1108/09513550610669185

Tang, J., Tang, Z., Zhang, Y., \& Li, Q. (2007). The impact of entrepreneurial orientation and ownership type on firm performance in the emerging region of China. Journal of Developmental Entrepreneurship, 12(4), 383-397. http://dx.doi.org/10.1142/S1084946707000733 
Thillainathan, R. (1976). In N. Truong (Ed.), The Role of Public Enterprise in National development in Southeast Asia: Problems and Prospects (pp. 1-149). Singapore: Regional Institute of Higher Education and Development.

Vermeulen, P. A. M. (2005). Uncovering Barriers to Complex Incremental Product Innovation in small and medium-sized financial services firms. Journal of Small Business Management, 43(4), $432-452$. http://dx.doi.org/10.1111/j.1540-627X.2005.00146.x

Wiklund, J., \& Shepherd, D. (2005). Entrepreneurial orientation and small business performance: a configurational approach. Journal of Business Venturing, 20, 71-91. http://dx.doi.org/10.1016/j.jbusvent.2004.01.001

Zahra, S. A., Ireland, R. D., Gutierrez, I., \& Hitt, M. A. (2000). Privatization and entrepreneurial transformation: Emerging issues and future research agenda. Academy of Management Review, 25(3), 509-524. 